\title{
Wireless Sensor Networks for Indoor Air Quality Monitoring
}

\author{
Doaa Hassan 1, S. M. El-Ghanam ${ }^{1}$, A. M. Abd El-Maksood², A. A. El-Magid", \\ F. A. S. Soliman ${ }^{2}$, and S. A. Kamh ${ }^{1}$ \\ 1.Electronics Research Lab., Physics Dept., Faculty of Women, \\ Ain Shams University, Cairo, Egypt. \\ 2.Nuclear Materials Authority, P. O. Box 530, Maadi - 11728, Cairo, Egypt.
}

\begin{abstract}
Wireless Sensor Networks (WSN) has been identified as one of the most important technologies for the $21^{\text {st }}$ century in the world of information technology. In the present paper, a simplified prototype self solar powered sensor node was demonstrated as a proof of concept which could be surveyed for real-time wireless detection systems. It was modeled using low cost and small-sized electronic components and wireless transceiver to serve the wireless communication capabilities. The proposed system was proved to be successfully applied in detecting, transmitting, and reporting, accurately, the changes in the levels of different physical parameters. Herein, WSN was concentrated on monitoring temperature and humidity, as an example, although it can carry-out up to eight/sixteen sensors for each single node, simultaneously. Finally, all the detected data in the monitored field was transmitted wirelessly, free of any noises, to the base station, where a receiver was installed on the computer to display, analyze and save the results and changes.
\end{abstract}

Keywords: Wireless sensor networks, prototype, solar power, wireless transceiver, temperature, humidity and base station.

\section{Introduction}

Wireless sensor network, generally abbreviated to WSN, is considered technically as one of the most important scientific revolutions in the field of wireless communications and embedded systems. WSNs attracted the attention of many researchers 0 2008, and Nor Azlina Abdel-Aziz, et al., 2009); they provide the means for autonomous monitoring of physical events in critical areas where human presence is not desirable or impossible (Xiangyang Li, 2008). In fact, the recent advances of sensing technology have been widely adopted to their rapid integration in new generation of monitoring applications in variety of fields such as: military applications, homeland and border security sector, crisis management, habitat monitoring, traffic surveillance, industrial monitoring, checking the safety of buildings and facilities, environmental monitoring, and health care applications (Chunyu Ai, et al., 2009, Peter Corke, et al., 2008, Ananthram Swami, et al., 2004, and You-Chiun Wang, 2008). In general, WSN consists mainly of distributed number of small, cheap, and low-power sensor nodes that cooperatively form a network. Each node links to neighboring nodes wirelessly to communicate with each other for monitoring physical phenomena like temperature, humidity, pressure, radiation, ... etc. (Peter Csaba Ölveczky, 2008, Peter Csaba Ölveczky, et al., 2009, Raja Jurdak, 2007, and 
Amol B. Bakshi, et al., 2008). Each sensor node has embedded processing capability and potentially has multiple onboard sensing devices. Sensor nodes cooperatively pass their data through the network to a main location which is called gateway, sink node or base station (Peter Corke, et al., 2010).

Although sensor networks have many applications, the environmental monitoring is a domain in which they may have a huge impact. However, the sensor nodes are scattered either inside the phenomenon or very close to it in the selected geographical area which may be rugged and dangerous environment or difficult to access where the environmental parameters of interest are needed to be measured. Hence, sensor network is used for studying interesting phenomena in particular geographical area, such as fire detection enabling querying of events in the area. Finally, an important issue to be studied is the fire detection using WSN where the fire manifestation must be early detected in order to prevent higher damages, lower the risk, and to avoid an environmental disaster. It is observable that, hundreds of possessions are destroyed every year caused by fire produces disastrous environmental, economical, social, material and general infrastructure consequences. Some cases could cause the death of the inhabitants of the affected zone or even cause combustion of important documents. Finally, when sensor detects a fire, it sends alarm through the wireless network to a central server. Based on, rapid call and dispatch firefighters or run the automatic fire extinguishing system in the exact location is required.

The proposed WSN system will be applied for detecting, transmitting, and reporting the changes in the levels of different physical parameters. Herein, it was concentrated on monitoring temperature and humidity, as an example, although it can carry-out up to eight/sixteen sensors for each single node, simultaneously.

\section{Materials and Methods}

Typically, in its simplest form (Fig. 1), each sensor node as in (Nitaigour P. Mahalik, 2007 and Shashi Phoha, et al., 2006) consists of:

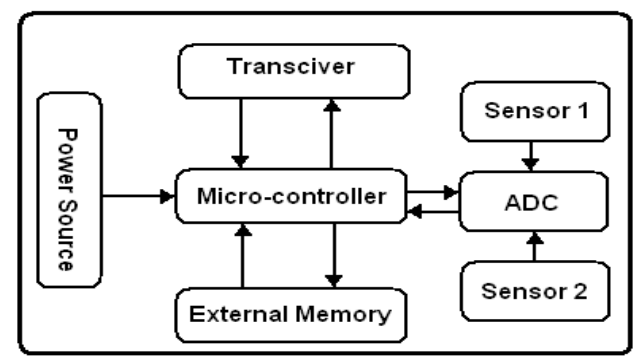

Fig. (1): Sensor node architecture.

- Microcontroller: it is a small computer on a single integrated circuit consisting of a relatively simple CPU combined with support functions such as a crystal oscillator, timers, clock, etc. A small memory is also often included on chip, as well as a typically small 
$\mathrm{read} /$ write memory. Microcontroller performs tasks, processes data and controls the functionality of other components in the sensor node.

- Transceiver: it is a device that has both transmitter and receiver capabilities on the same chip in which there are common circuits between them.

- External Memory: there are two categories of memory based on the purpose of storage :

1) User memory, which is used for storing personal data.

2) Programmable memory, which is used for programming the device.

- Power source: power consumption in the sensor node is for the sensing, communication and data processing. More energy is required for data communication in sensor node. Batteries are the main source of supply of sensor nodes. Technically, current sensors are developed which are able to renew their energy from solar, thermo-generators, or vibration energy.

- Sensors: those are hardware devices that produce measurable response to any change in a physical conditions like temperature, humidity, air quality, light, rain gauges, .........etc. and convert it into electrical signal. The continual analog signal sensed by the sensors is digitized by an analog-to-digital converter supported by microcontrollers for further processing. Characteristics and requirements of sensor node should be small size, consume extremely low energy, operate in high volumetric densities, and adaptive to the environment (B. Krishnamachari, 2005).

In the following subsection, a brief description of each subsystem building block is being discussed.

\section{Results and Discussions}

\subsection{Wireless Module}

The used smart radio serial transceiver modules are of the model RF1100-232 (Fig. 2). It is half-duplex UART (Universal Asynchronous Receiver/Transmitter) interface wireless transmission module that can work in $433 \mathrm{MHz}$ common band (Electronics IntroductionMarcmart, 2012). The module uses high-performance baseband crystal oscillator that meets the requirements of industrial environments. It is mainly used in low-speed long-distance communications. Finally, from a signal point of view, the wireless module has six terminals that are listed in Table (1).

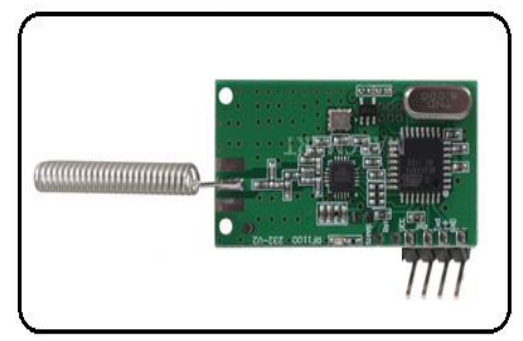

Fig. (2): Smart radio serial transceiver module.
Table (1): RF1100-232 pin description interface.

\begin{tabular}{|c|c|c|c|}
\hline Pin & Signal & Direction & Description \\
\hline 1 & Gnd & N/A & Signal ground \\
\hline 2 & TxD & Output & Transmitted data \\
\hline 3 & $\mathrm{RxD}$ & Input & Received data \\
\hline 4 & $\mathrm{~V}_{\mathrm{cc}}$ & Input & Power supply \\
\hline 5 & Sleep & - & $\begin{array}{l}\text { Neither transmit } \\
\text { nor receive packets }\end{array}$ \\
\hline 6 & Set & $\overline{-}$ & Setting Data \\
\hline
\end{tabular}




\subsection{Microcontrollers}

Arduino microcontroller is a single-board microcontroller, intended to make building interactive objects or environments more accessible (T. E. Murphy, 2012 and W. Durfee, 2011). The hardware consists of an open-source hardware board designed around an 8-bit Atmel AVR microcontroller, or a 32-bit Atmel ARM. Current models feature a USB interface, 6 analog input pins, as well as 14 digital I/O pins that accommodate various extension boards. It comes with a simple integrated development environment (IDE) that runs on regular personal computers and allows users to write programs for Arduino using $\mathrm{C}$ or $\mathrm{C}++$. Finally, there are many version types of the Arduino boards; the Arduino Uno, the simplest one to be used through the present work (Fig. 3).

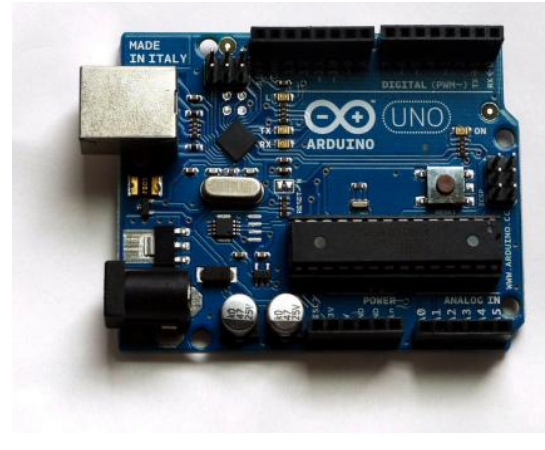

(a)

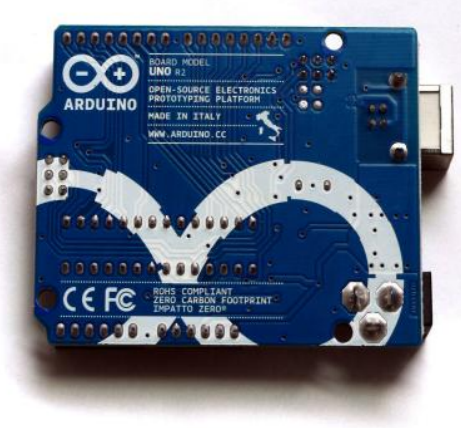

(b)

Fig. (3): Front (a) - and back (b) - views of Arduino Uno.

\subsection{Sensors}

For simplicity, two environmental parameters only (temperature and humidity) were considered to be monitored through the present work while it is easier to add more sensors (additional six sensors) to the same sensor node system. Noting that, such nodes can carry-out up to $8 / 16$ sensors. As a consequence, the current subsection is specialized for studying the specifications and calibration of both the used temperature and humidity sensors.

\subsubsection{Temperature Sensor}

Nowadays, there are many types of temperature sensors come with different output forms and temperature ranges such as thermocouple, thermistor and infrared. In the present context, LM35 type was chosen as a temperature sensor due to its simplicity, high sensitivity and accuracy, as well, low cost. The LM35's low output impedance, precise inherent calibration and linear output make interfacing to readout or control circuitry especially easy. In addition, the LM35 is suitable for normal use in weather temperature measuring where it is rated to operate over a $-55^{\circ}$ to $+150^{\circ} \mathrm{C}$ temperature range. Also, such sensor series are precision integrated-circuit temperature ones, whose output voltage is linearly proportional to the Celsius (Centigrade) temperature. Figure (4) shows LM35 sensor and its calibration curve, where it has been tested under the effect of different temperature levels, in the range from $20^{\circ} \mathrm{C}$ up to $110^{\circ} \mathrm{C}$. 


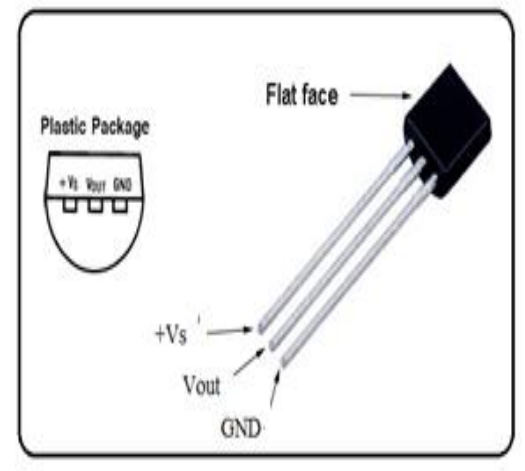

(a) LM35 sensor bottom view, pins out and packaging

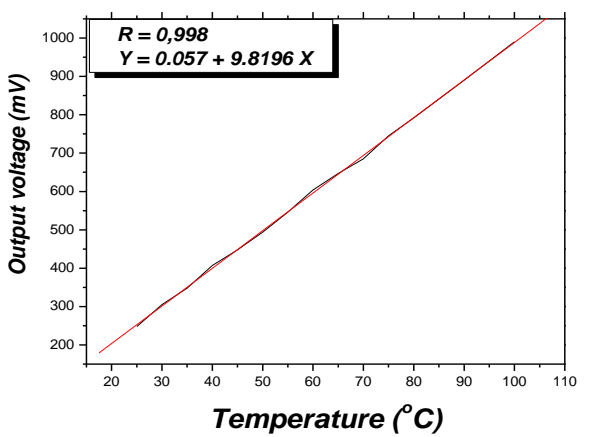

(b) calibration curve

Fig. (4): LM35 sensor and its calibration curve.

\subsubsection{Humidity Sensor, DHT11}

The humidity sensor of the type DHT11 and its module are shown in Fig. (5). In general, the sensor is calibrated with a digital signal output. It can ensure high reliability and excellent long-term stability by using the exclusive digital-signal-acquisition technique and humidity sensing technology. Also, such sensors incorporate a humidity measurement component which is resistive type and a negative temperature coefficient temperature measurement component. The calibration coefficients of the sensor are saved in the onetime programmable memory as programmers. These coefficients are used by the DHT11's internal signal while calculating humidity. Besides, the single-wire serial interface makes framework joining fast and simple. In addition, the sensor works on a very low power, its size is very small and can transmit signal upto-20 meter. Finally, the humidity measurement of such sensors ranges from $20 \% \mathrm{RH}$ up to $90 \% \mathrm{RH}$ with an accuracy of $\pm 5 \% \mathrm{RH}$.

The proposed sensor configuration and connection are shown in Fig. (6). In this concern, Pin (1) is the power supply one, where a VDC value of 3.0 - 5.5 Volts is required. When the sensor is powered, no instructions should be given to the sensor up to one second so as to pass the unstable status. On the other hand, Pin (2) is the data pin, where the data has decimal and integral parts.

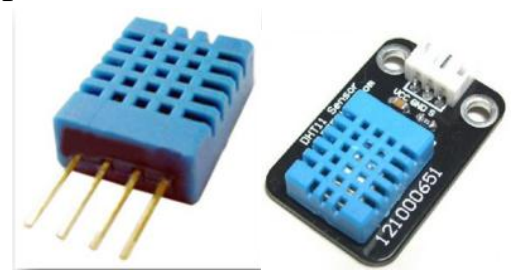

Fig. (5): DHT11 humidity sensor ant its module.

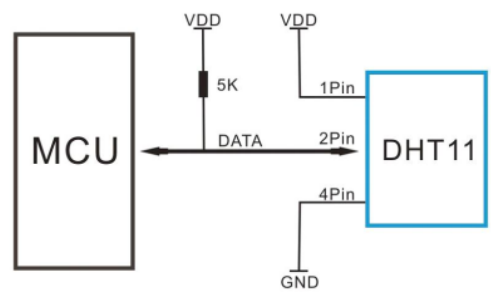

Fig. (6): DHT11 Pin Configuration and Connection.

At first, the microcontroller unit gives a start signal, then the mode of DHT11 changes to the running-mode from the low-power-consumption mode. Then DHT11 waits for micro- 
controller unit for the completion of the start signal. It gives a response signal of 5 byte data after its completion. This signal includes the temperature and relative humidity information to MCU.

\subsection{Power Source}

The sensor node consumes power for sensing, communicating and data processing as indicated in Fig. (7). More energy is required for data communication than any other process.

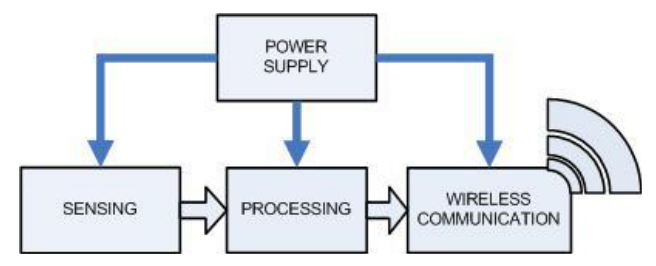

Fig. (7): Basic blocks of a wireless node.

Batteries, both rechargeable and non-rechargeable, are the main source of power supply for sensor nodes. Prolonging battery life is a principal objective in the design of WSNs due to the difficulty and high cost associated with replacing or recharging exhausted batteries in a deployed network. Hence, the self rechargeable batteries are preferable to use in sensor nodes like solar powered widget board as shown in Fig. (8).

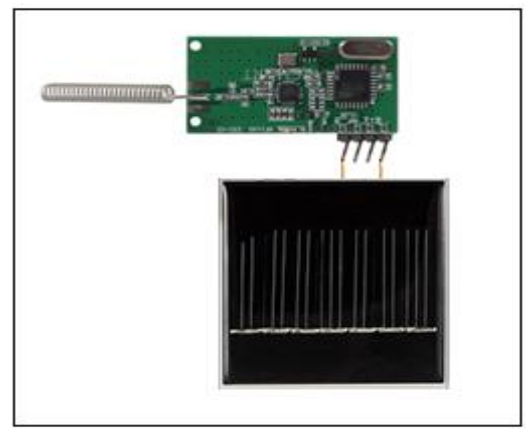

Fig. (8): Sensor node and solar panel.

\subsection{Wireless Sensor Network Prototype}

As already described before, WSN basically composed of two main parts :

1- Sensor node which perform as a transmitter port.

2- Base station/gateway/sink node symbolizes the receiver port.

\subsubsection{Sensor Node Design Technique and Description}

The design of sensor node system includes modeling and setting up of the wireless system of sensor node to test the validity in detecting, transmitting, and reporting, accurately, the changes in the levels of different physical parameters. Herein, WSN was concentrated on monitoring temperature and humidity, as an example, although it can carry-out up to eight/sixteen sensors for each single node, simultaneously. It is worthy to be noted that the proposed node system has the availability of carrying-out different numbers of sensors on the 
same sensor board. That is, it could be developed for monitoring number of sensors such as radiation, temperature, humidity, and pressure ...etc., all on the same board. The required sensors are connected in their suitable locations to the microcontroller pins and suitable modifications are achieved in the programming code to keep pace with these changes. In this concern, the block diagram of temperature / humidity sensor connected to the proposed microcontroller is shown in Fig. (9).

The Arduino UNO microcontroller is programmed to transmit, for example, the humidity and temperature sensors reading data serially (at 9600 baud rate with 8-bit data stream). The Arduino's analog pins ( $\mathrm{A}_{0}$ and $\mathrm{A}_{1}$, respectively) feeds the data into the receiving pin of the wireless module which transmits it using $433 \mathrm{MHz}$ ASK RF signal. On the receiving station, the module receives the data and its output is connected to the computer to display the received bytes. Through this demo, the interfacing of low cost RF modules which is serial data transmitter/receiver pair for transmitting data between remotely located sensor node and sink node $(\mathrm{Pc})$ was achieved.

In order to accomplish this evaluation, firstly, the phase is implemented to the simulation model, before practical hardware prototyping applications, using Electronic Lab Center PROTEUS VSM - interactive circuit simulation program. Consequently, the overall system was designed and tested using Electronic Lab Center PROTEUS. In which, the simulation result of the proposed circuit was presented in Fig. (10).

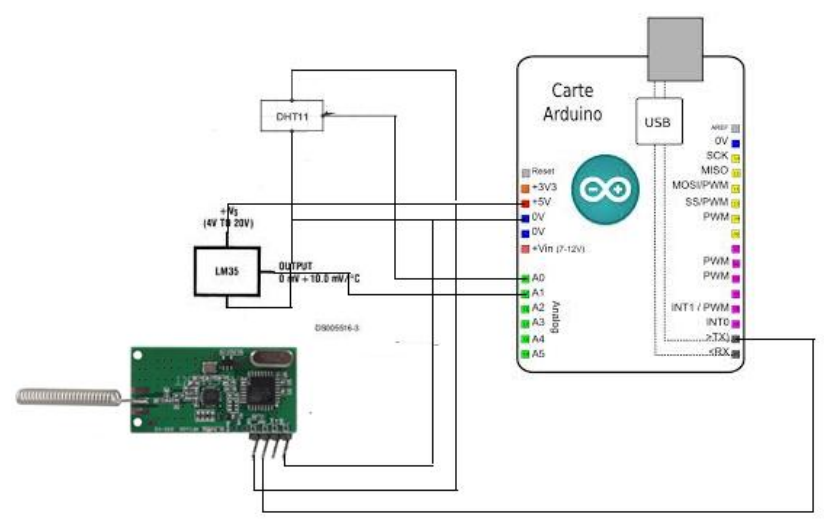

Fig. (9): Sensor node designing architecture.

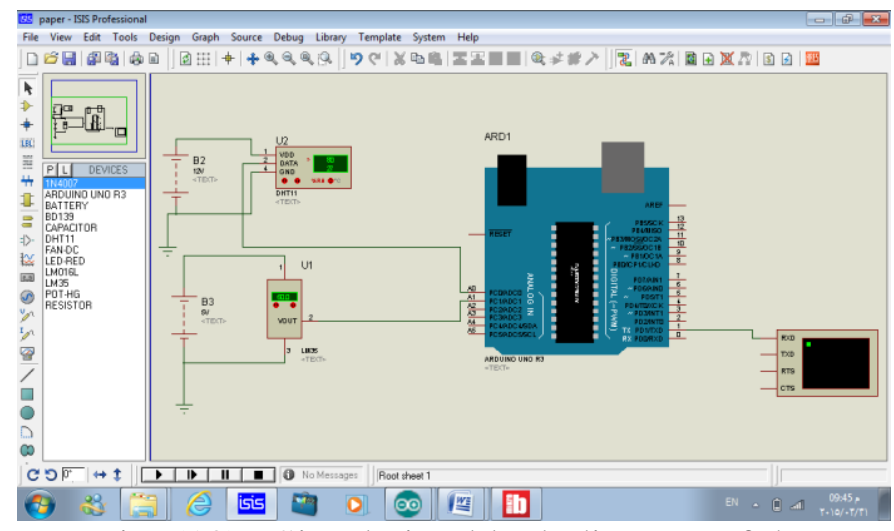

Fig. (10): Simulation block diagram of the humidity and temperature sensor node.

Finally, the physical implementation of the sensor node on the breadboard was shown in Fig. (11), in which, the system works perfectly well.

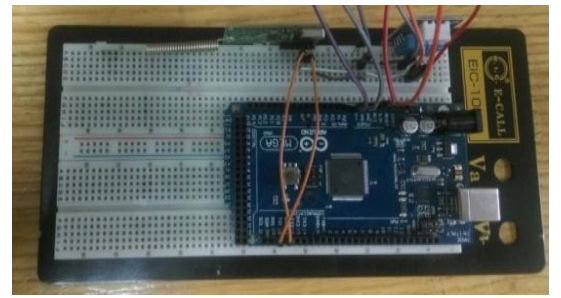

Fig. (11): System set up of temperature and humidity sensors node. 


\subsubsection{Wireless Receiver Architecture}

The second part of the proposed wireless system is the wireless receiver; which represents the base station that will receive the information from sensor node. In principle, the base station is mainly composed of an identical RF transceiver module acts as receiver connected to a computer via USB. In this concern, Fig. (12) shows the RF1100-232 module connected to a FTDI USB to serial converter. The serial port on the module is a TTL level port, it uses 0 Volt and +5.0 Volts levels. As a result, the GND and $\mathrm{V}_{\mathrm{cc}}$ ports of RF1100-232 module were connected to their instances pins in USB port to get their power.

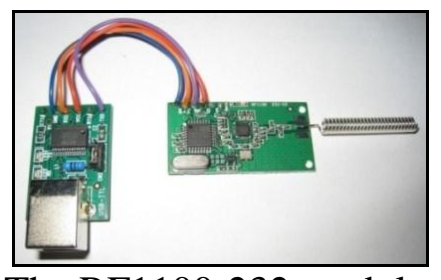

Fig. (12): The RF1100-232 module connected to a FTDI USB to serial converter.

The humidity and temperature data are being transferred via a smart wireless media to a central base station and read out through the MICROBASIC Pro for PIC program periodically each minute for example. In addition, the captured screenshot of the receiving data is indicated in Fig. (13).

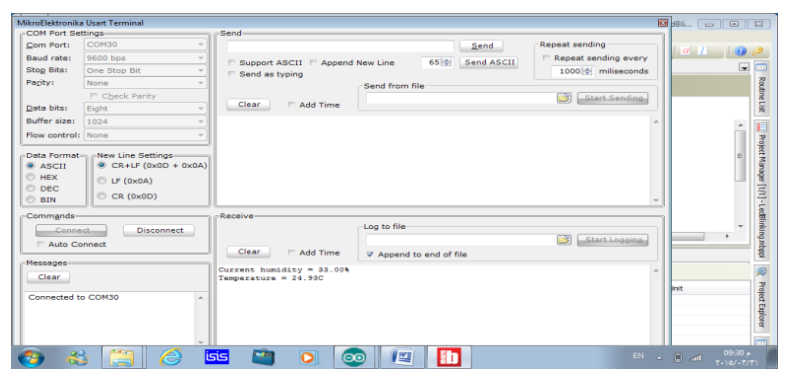

Fig. (13): Snapshot of the received data via the wireless system.

Broadly, the receiving data is indicated and plotted via programmed code written in MATLAB R2009a. Another feature has been added to the investigated wireless system design that is; in case of the normal levels for the environmental parameters, the data will be plotted and displayed with green color (safe limit) as shown in Fig. (14a). While, for levels exceeding certain threshold value $\left(35{ }^{\circ} \mathrm{C}\right.$ and $30 \%$ for temperature and humidity sensor respectively, as an example), the data will be plotted and displayed with yellow color which is considered as abnormal case in sending the corresponding data. Moreover, if the detected data exceed the abnormal limit to dangerous limit (from $80^{\circ}$ and $60 \%$ up to $110^{\circ}$ and $100 \%$ ), the plotted line converted instantly to red color to indicate the risky case (fire detection for example). For more clarification, Fig. (14b) shows the case of applying external high temperature effect on the temperature sensor. 


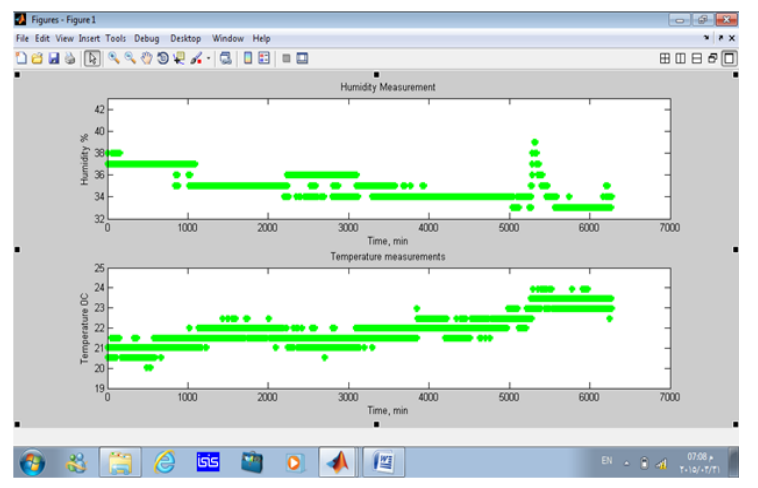

(a)

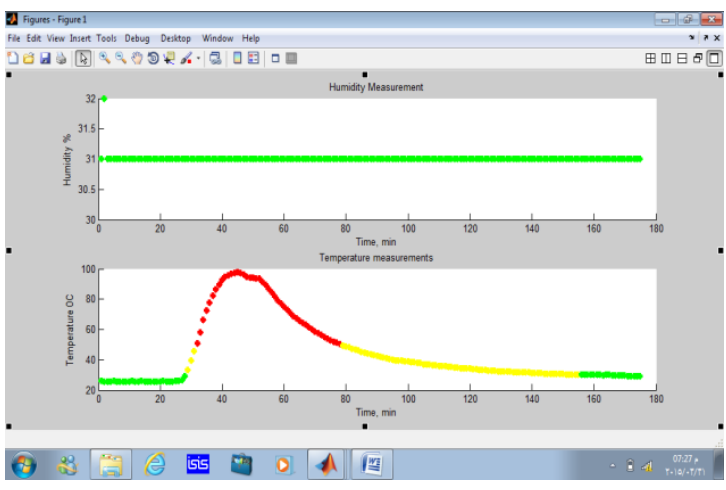

(b)

Fig. (14): Snapshot of normal (a) and abnormal (b) humidity and temperature data, plotted via the MATLAB program.

\section{Conclusion}

The proposed paper presents the development of an automatic wireless sensor for real time monitoring of temperature and humidity. A simplified sensor node prototype was demonstrated as a proof of the paper concept. For simplicity, only two environmental parameters are considered to be monitored through the work, although the node can carry-out up to eight/sixteen sensors simultaneously. As well, more and more nodes can be operates in parallel. The proposed wireless node is characterized with different advantages namely: simplicity, high speed, low cost, and high accuracy. In addition, if the wireless node detects an abnormal increase in the environ-mental reading of any sensor, it sends an alarm message through the wireless network, as well, sends the data continuously to a central server to be plotted with different colours.

\section{References}

Amol B. Bakshi and Viktor K. Prasanna, "Architecture-Independent Programming for Wireless Sensor Networks”, John Wiley \& Sons, Inc., Canada, Vol. 61, (2008).

Ananthram Swami, Qing Zhao, Yao-Win Hong and Lang Tong, "Wireless Sensor Networks Signal Processing and Communications Perspectives", John Wiley \& Sons, England, 2007.

Bhaskar Krishnamachari, "Networking Wireless Sensors", Cambridge University Press, New York, Ch. 1, 2005.

Chunyu Ai, Hailong Hou, Yingshu Li and Raheem Beyah, "Authentic delay bounded event detection in heterogeneous wireless sensor networks", Ad Hoc Networks, Vol. 7, pp. 599-613, 2009.

Electronics Introduction-Marcmart, "RF1100-232Wireless Transparent RF Transceiver Module - 433 MHz CC1101 with Antenna (OT121)”, 2012.

Feng Zhao and Leonidas J. Guibas , "Wireless Sensor Networks: An Information Processing Approach", Elsevier, California, Ch. 1, 2004. 
Krzysztof Iniewski, "Wireless Technologies Circuits, Systems, and Devices", Taylor \& Francis, USA, 2008.

Margaret Rouse, "Integrated Development Environment; IDE", Search Software Quality, Feb. 2007.

Nitaigour P. Mahalik, "Sensor Networks and Configuration Fundamentals, Standards, Platforms, and Applications", Springer-Verlag, Berlin Heidelberg, 2007.

Nor Azlina Ab. Aziz, Kamarulzaman Ab. Aziz, and Wan Zakiah Wan Ismail, "Coverage Strategies for Wireless Sensor Networks”, World Acad. of Sci., Eng. and Tech., Vol. 50, pp. 145-150, 2009.

Peter Corke, Tim Wark, Raja Jurdak, Wen Hu, Philip Valencia and Darren Moore, "Environmental Wireless Sensor Networks", Communications, 2008 IEEE Intr. Zurich Seminar, pp. 98-101, 2008.

Peter Csaba Ölveczky and Stian Thorvaldsen, "Formal modeling, performance estimation, and model checking of wireless sensor network algorithms in Real-Time Maude", Theoretical Computer Sci., Vol. 410, pp. 254-280, 2009.

Raja Jurdak, "Wireless Ad Hoc and Sensor Networks A Cross-Layer Design Perspective", Springer Media, 2007.

R. Rehman, and C. R. Paul., "The Linux Development Platform: Configuring, Using and Maintaining a Complete Programming Environment", 2002.

Shashi Phoha, Thomas LaPorta and Christopher Griffin, "Sensor Network Operations", John Wiley \& Sons, Inc., Institute of Electrical and Electronics Engineers, USA, 2006.

T. E. Murphy, "Introduction to the Arduino microcontroller ", Hands-on Research in Complex Systems Shanghai Jiao Tong Univ., June 17 - 29, 2012.

W. Durfee, “Arduino Microcontroller Guide”, Version Oct. 2011.

Xiangyang Li, "Wireless Ad Hoc and Sensor Networks Theory and Applications", the Edinburgh Building, Cambridge, UK, 2008.

You-Chiun Wang, Chun-Chi Hu, and Yu-Chee Tseng," Efficient Placement and Dispatch of Sensors in a Wireless Sensor Network", IEEE Trans. on Mobile Computing, Vol. 7, No. 2, pp. 262-274, 2008. 


\section{الملذص باللغة العربية}

\section{شبكات الأستشعار اللاسلكية لمراقبة درجة نقاء الهواء داخل المنشأت}

دعاء حسن حنفي(1) - صفاء محمد رشدي الغنام(1) - أثرف مصلح عبدالمقصود (2) - أمبرة عبدالمجيد أبوطالب(1)

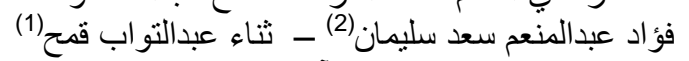
1 ـ معمل أبحاث الإلكترونيات ـ قسم الفيزياء ـ كلية البنات للادداب و العلوم او التربية - جامعة عين شمس - القاهرة - جمهورية مصر العربية r - هيئة المواد النووية - ص ـ.ب. 530 - المعادي 11728 ـ القاهرة - جمهورية مصر العربية

\section{الملخـص العربسي}

تعتبر شبكات الاستشعار اللاسلكية والتي يثار لها اختصار اً (WSN ) واحدة من أهم الثورات العلمية في مجال

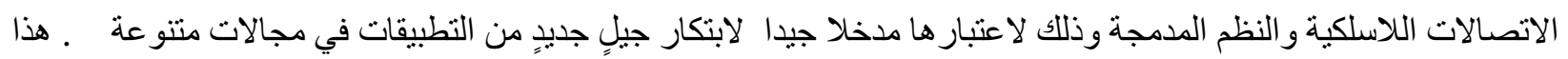
ولا يقتصر الأمر على استخدام شبكات الاستشعار اللاسلكية في التطبيقات العسكرية فقط بل امتد استخدامها ليشمل المجالات الطبية و الصناعية والتجارية و غير ها من التطبيقات كالكثف المبكر لحر ائق الغابات والفيضانات ورصد الأحوال الجوية و المر اقبة الصحية وفحص سلامة الأبنية و المنشآت و إدارة ومر اقبة حركة المرور . هذا بالإضافة إلى تطبيقات استخدامها في

المجال الأمني للكثف عن المتسللين و عمليات اقتحام المناطق المحظورة، ومن التطبيقات الهامة فى مجال شبكات الاستشعار اللاسلكية إمكانية المر اقبة والتحكم عن بعد فى العديد من الظو اهر الفيزيائية مختلفة ومتعددة مثل الحرارة و الرطوبة وما إلى غير ذلك من خلال أجهزة لاسلكية صغيرة الحجم، علما بأن هذه الأجهزة تحتوي على مجسات تقوم بالتقاط وجمع المعلومات

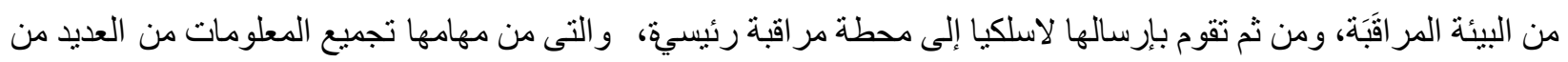
أجهزة الاسستشعار اللاسلكية الصغيرة والمنتشرة فى البيئة المر اد مر اقبتها ، وتعمل المحطة على معالجة وتحليل المعلومات المستقبلة لاتخاذ القرارات المناسبة.

هذا بالإضافة إلى أنه في حالة حدوث زيادة غير متوقعة عن الحد المسموح لأي من هذه المعاملات الفيزيائية فإنه يتم إرسال رسالة إنذار وتقرير من خلال أجهزة الاستشعار التي رصدت تللك الظاهرة لمحاولة سر عة السيطرة على تلك المخاطر، ففي حالة زيادة درجة الحرارة فإنه يكون من المتوقع حدوث حريق في هذا المكان و على أساس ذلك يتم التعامل السريع بإرسال رجال الإطفاء أو تشغيل نظام الإطفاء الآلي في المكان المحدد.

يهدف البحث قيد الدر اسة إلى تصميم نموذج تجريبي مقترح لنظام رصد بيئى بعتمد على انشاء شبكة لاسلكية متعددة

المجسات لمتغيرات فيزيائية، منها على سبيل المثال الحرارة والرطوبة، وفى هذا الصدد يجدر الاشارة انه ثبت لارجة عالية من الكفاءة امكانية استخدام ثمــــانية مجسات مختلفة اعتمادا على وحدة تحكم الكترونى (Arduino Ano)، متصلة بوحدة ارسال/استقبال لاسلكية (Wireless transceiver network) لإرسال المعلومات لاسلكيا إلى جهاز استقبال مثبت على جهاز

حاسب آلي لعرض وملاحظة وحفظ النتائج و التغيرات، هذا وقد أثنتت التجارب العملية مدى الكفاءة العالية عند الاستخدام، إضافة الى رخص تكلفة وصغر حجم محطة الرصد المقترحة و التى لاتتعدى سنتيمتر ات مربعة. الأمر الذى يساهم بقدر عظيم فى نشر تللك التقنية فى العديد من الأماكن ذات الأهمية. 